\title{
Helicobacter ganmani sp. nov., a urease- negative anaerobe isolated from the intestines of laboratory mice
}

1 School of Microbiology and Immunology, The University of New South Wales, Sydney, NSW 2052, Australia

2 Laboratorium voor Microbiologie, Universiteit Gent, Ledeganckstraat 35, B-9000 Gent, Belgium

3 Danish Veterinary Laboratory, Bülowsvej 27, DK-1790 Copenhagen V, Denmark

\author{
Bronwyn R. Robertson, ${ }^{1} \dagger$ Jani L. O' Rourke, ${ }^{1}$ Peter Vandamme, ${ }^{2}$ \\ Stephen L. W. On ${ }^{3}$ and Adrian Lee ${ }^{1}$
}

Author for correspondence: Bronwyn R. Robertson. Tel: +61 29385 1241. Fax: +61293851050. e-mail: b.robertson@unsw.edu.au
Keywords: Helicobacter ganmani, Helicobacter rodentium, phylogeny, 16S rDNA, SDS-PAGE

\section{INTRODUCTION}

The discovery and culture of Helicobacter pylori by Marshall et al. (1984) reinvigorated the field of gastrointestinal microbiology and led to the establishment of a new genus of bacteria with the transfer of H. pylori and Helicobacter mustelae from the genus Campylobacter in 1989 (Goodwin et al., 1989). Since the establishment of this genus, the number of recog-

\footnotetext{
† Present address: Clive and Vera Ramaciotti Centre for Gene Function Analysis, School of Biochemistry and Molecular Genetics, The University of New South Wales, Sydney, NSW 2052, Australia.

Abbreviation: SPF, specific pathogen-free.

The GenBank/EMBL/DDBJ accession numbers for the 16S rDNA sequences determined in this study are AF000221-AF000224.
}

nized species has risen dramatically, currently standing at 18 formally named, and two provisional (Candidatus), species. The normal site of colonization for all of these bacteria is the gastrointestinal tract, with isolates being divided between gastric and intestinal colonizers. Species have been isolated from a wide variety of mammals and birds with the intestinal colonizers making up well over half of the described species. Phylogenetically, the genus Helicobacter is found within the $\varepsilon$-subclass of the class Proteobacteria (Murray et al., 1990). This separate bacterial lineage has also been defined as rRNA superfamily VI (Vandamme et al., 1991) keeping in line with the distinction of rRNA superfamilies within the Proteobacteria (De Ley, 1992). Other genera found within this subclass include Campylobacter and Arcobacter, 
which together make up the family Campylobacteraceae (Vandamme \& De Ley, 1991).

The discovery of several murine helicobacters has led to uncertainties about the suitability of some laboratory mice for helicobacter vaccine studies and the validity of a number of past studies in other areas of biomedical research. In $H$. pylori vaccine research, prior antigen exposure is important in terms of host immune response and the use of mouse models in which animals have been, or still are, naturally infected with other Helicobacter species is significant. Furthermore, several murine Helicobacter species are themselves associated with disease in some infected animals. Mice infected with Helicobacter hepaticus can develop chronic liver inflammation and, in some strains of mice, hepatocellular carcinoma after longterm infection (Fox et al., 1994; Fox \& Wang, 1997). $H$. hepaticus infection has been shown to be widespread among commercially available mice in the USA (Shames et al., 1995). Helicobacter bilis has also been associated with hepatitis in aged, inbred strains of mice (Fox et al., 1995) and, like H. hepaticus, was isolated from commercially available mice (Shames et al., 1995). Other Helicobacter species that have been found to colonize the murine intestinal tract include Helicobacter muridarum (Lee et al., 1992), Helicobacter trogontum (Mendes et al., 1996) and Helicobacter rodentium (Shen et al., 1997). The misnamed 'Flexispira rappini' has also been isolated from the mouse intestinal tract (Schauer et al., 1993). As the mouse represents a convenient and widely used animal model for $H$. pylori infection, workers in the field must be vigilant in detecting natural infections with other Helicobacter species in laboratory mice.

During such a survey of spiral bacteria infecting mice obtained from four animal facilities in Sydney, Australia, we cultured a novel species of Helicobacter, for which we propose the name Helicobacter ganmani. The description takes into account the recent proposal of minimal standards for describing new species of the genus Helicobacter (Dewhirst et al., 2000), and pays special attention to a comparison with $H$. rodentium, the most closely related species, also isolated from laboratory mice (Shen et al., 1997). Isolates of the proposed species were characterized using morphological, biochemical, physiological and genetic methods.

\section{METHODS}

Bacterial isolation and cultivation. Conventional or Specific Pathogen-Free (SPF) Quackenbush/Swiss mice $(n=23)$ were obtained from four separate animal facilities in Sydney, Australia. Routine screening for spiral bacteria was carried out by culturing intestinal mucus scrapings and homogenized liver samples on blood agar (BA) containing Blood Agar Base No. 2 (Oxoid) plus 5\% horse blood, or on Campylobacter selective agar (CSA) containing BA supplemented with amphotericin $\left(2 \cdot 5 \mu \mathrm{g}\right.$ Fungizone $\mathrm{ml}^{-1}$; E. R. Squibb) and Skirrow's selective supplement $(2.5 \mu \mathrm{g}$ polymyxin $\mathrm{B} \mathrm{ml} \mathrm{l}^{-1}, 10 \mu \mathrm{g}$ vancomycin $\mathrm{ml}^{-1}, 5 \mu \mathrm{g}$ trimethoprim $\mathrm{ml}^{-1}$ ). Mouse intestinal mucus scrapings or homo- genized livers were inoculated directly onto fresh, moist BA and CSA. Alternatively, filters with a pore size of $0.65 \mu \mathrm{m}$ (Millipore) were placed onto the surface of plates and mucus scrapings or homogenized livers were inoculated onto the centre of the filters and plates placed in a $37^{\circ} \mathrm{C}$ incubator set at $10 \% \mathrm{CO}_{2}$ and $95 \%$ humidity for $2 \mathrm{~h}$. After this time the filters were removed. All plates were incubated, lids uppermost, in an anaerobic jar (HP 11; Oxoid) with a microaerobic gas-generating kit (BR 56; Oxoid) or with an anaerobic gas-generating kit (BR 38; Oxoid) at $37^{\circ} \mathrm{C}$ for 72-96 h. After incubation, plates were examined for growth of spiral bacteria using phase-contrast microscopy. Suspect colonies were subcultured until pure cultures were obtained.

Electron microscopy. Fresh bacterial cultures were fixed in $1 \%$ glutaraldehyde for 1 min then transferred to cacodylate buffer $(0 \cdot 1 \mathrm{M}$ sodium cacodylate- $\mathrm{HCl}, \mathrm{pH} 7 \cdot 4)$. Bacteria were negatively stained with phosphotungstic acid (1\%) and viewed with an Hitachi H7000 transmission electron microscope.

DNA extraction. DNA was extracted from a loopful of cells using a modification of the bacterial lysis method of Tillett \& Neilan (2000). Cells were resuspended in $1 \mathrm{ml} \mathrm{XS} \mathrm{buffer}$ containing $0.01 \%(\mathrm{w} / \mathrm{v})$ potassium ethyl xanthogenate (Fluka Chemika), $0.8 \mathrm{M}$ ammonium acetate, $0 \cdot 1 \mathrm{M}$ Tris/ $\mathrm{HCl}(\mathrm{pH} \mathrm{8.0)}, 20 \mathrm{mM}$ EDTA (pH 8.0) and $1 \%(\mathrm{w} / \mathrm{v})$ SDS and mixed by vortexing for $10 \mathrm{~s}$. The solution was incubated at $70{ }^{\circ} \mathrm{C}$ for $30 \mathrm{~min}$, vortexed for $10 \mathrm{~s}$ and cooled on ice for $30 \mathrm{~min}$. The tube was centrifuged at 15000 r.p.m. for $10 \mathrm{~min}$ at $4{ }^{\circ} \mathrm{C}$ and the supernatant carefully removed into a new microcentrifuge tube. The supernatant, containing genomic DNA, was precipitated by the addition of an equal volume of 2-propanol and incubated at room temperature for $10 \mathrm{~min}$. The DNA was collected by centrifugation at 15000 r.p.m. for $20 \mathrm{~min}$ at $4{ }^{\circ} \mathrm{C}$. The resulting pellet was washed with $70 \%$ ethanol, dried using a vacuum desiccator then resuspended in $200 \mu \mathrm{l}$ TE buffer $(10 \mathrm{mM}$ Tris $/ \mathrm{HCl}, 1 \mathrm{mM}$ EDTA, pH 8.0). An aliquot of DNA was diluted 1/10 in distilled water for use in PCR applications.

PCR amplification and sequencing. Typically, amplification reactions included $1 \times$ reaction buffer $[67 \mathrm{mM}$ Tris $/ \mathrm{HCl}$, $16 \mathrm{mM}\left(\mathrm{NH}_{4}\right)_{2} \mathrm{SO}_{4}, 0.45 \%$ Triton X-100, $0.2 \%$ gelatin], 1 unit Taq DNA polymerase (Biotech International), $200 \mu \mathrm{M}$ each dNTP, $2 \mathrm{mM} \mathrm{MgCl}_{2}$, 10 pmol each oligonucleotide primer and $1 \mu$ diluted DNA (approx. 20-100 ng) in a final volume of $50 \mu \mathrm{l}$. Two Helicobacter genus-specific PCRs were used to screen isolates using primers F27(UFP) and R274 or primers H276f and H676r (Table 1). Both these reactions were performed as has been described previously (Lee et al., 1997; Riley et al., 1996). PCR amplification of the $16 \mathrm{~S}$ rDNA was achieved using primers F27(UFP) and R1492(URP) (Table 1). Here, cycling conditions included an initial denaturation at $94^{\circ} \mathrm{C}$ for $3 \mathrm{~min}$ then five cycles of $94{ }^{\circ} \mathrm{C}$ for $45 \mathrm{~s}, 53{ }^{\circ} \mathrm{C}$ for $30 \mathrm{~s}$ and $72{ }^{\circ} \mathrm{C}$ for $1 \mathrm{~min}$, followed by 28 cycles of $94{ }^{\circ} \mathrm{C}$ for $45 \mathrm{~s}, 48^{\circ} \mathrm{C}$ for $30 \mathrm{~s}$ and $72{ }^{\circ} \mathrm{C}$ for $1 \mathrm{~min}$. A final extension step at $72^{\circ} \mathrm{C}$ for $10 \mathrm{~min}$ was carried out at the end of the amplification. Thermocycling was performed in an FTS-320 Thermal Sequencer (Corbett Research). All PCR products were separated on agarose mini-gels in TAE buffer ( $40 \mathrm{mM}$ Tris-acetate, $1 \mathrm{mM}$ EDTA) and photographed under UV transillumination after staining with ethidium bromide. Whole length 16S rDNA PCR products were purified prior to sequencing using the Prep-AGene DNA Purification System (Bio-Rad). Amplified DNA was then directly sequenced using the ABI PRISM Ready Reaction DyeDeoxy Terminator Cycle Sequencing Kit (PE Applied Biosystems) and the GeneAmp PCR System 2400 
Table 1. 16S rDNA amplification and sequencing primers

Underlined sequences are those of the universal sequencing primers (UFP and URP) that were attached to assist in successive sequencing reactions.

\begin{tabular}{|c|c|c|}
\hline Primer & Sequence $\left(5^{\prime}-3^{\prime}\right)$ & Reference \\
\hline \multicolumn{3}{|l|}{ Amplification } \\
\hline F27(UFP) & TAGTGTAAAACGACGGCCAGTAGAGTTTGATCCTGGCTCAG & Neilan et al. (1997) \\
\hline R1492(URP) & TAGCAGGAAACAGCTATGACACGGTTACCTTGTTACGACTT & Neilan et al. (1997) \\
\hline $\mathrm{R} 274$ & TCTCAGGCCGGATACCCGTCATAGCCT & Fox et al. (1992) \\
\hline $\mathrm{H} 276 \mathrm{f}$ & CTATGACGGGTATCCGGC & Riley et al. (1996) \\
\hline H676r & АТТССАССТАССТСТСССА & Riley et al. (1996) \\
\hline D86 & GTCCTTAGTTGCTAACTATT & Shen et al. (1997) \\
\hline D87 & AGATTTGCTCCATTTCACAA & Shen et al. (1997) \\
\hline \multicolumn{3}{|l|}{ Sequencing } \\
\hline $27 \mathrm{~F}$ & AGAGTTTGATCCTGGCTCAG & $\begin{array}{l}\text { Neilan et al. (1997), } \\
\text { Weisburg et al. }(1991)\end{array}$ \\
\hline $119 \mathrm{~F}$ & GTGGCGGACGGGTGAGTA & Weisburg et al. (1985) \\
\hline $341 \mathrm{R}$ & CTGCTGCCTCCCGTAGG & $\begin{array}{l}\text { Neilan et al. (1997), } \\
\text { Weisburg et al. (1985) }\end{array}$ \\
\hline $530 \mathrm{~F}$ & GTGCCAGCAGCCGCGG & $\begin{array}{l}\text { Neilan et al. (1997), } \\
\text { Weisburg et al. (1985) }\end{array}$ \\
\hline $685 \mathrm{R}$ & TCTACG(G/C)ATTT(T/C)ACCGCTAC & Weisburg et al. (1985) \\
\hline 929R & TCC(T/A)CCGCTTGTGCGGGG & $\begin{array}{l}\text { Neilan et al. (1997), } \\
\text { Weisburg et al. (1991) }\end{array}$ \\
\hline $942 \mathrm{~F}$ & GGGCCCGCACAAGCGG & $\begin{array}{l}\text { Neilan et al. (1997), } \\
\text { Weisburg et al. (1985) }\end{array}$ \\
\hline $1221 \mathrm{R}$ & ATTGTAG(T/C)ACGTGTGTAGCC & $\begin{array}{l}\text { Neilan et al. (1997), } \\
\text { Weisburg et al. (1985) }\end{array}$ \\
\hline $1241 \mathrm{~F}$ & GCTACACACGT(A/G)CTACAATG & $\begin{array}{l}\text { Neilan et al. (1997), } \\
\text { Weisburg et al. (1985) }\end{array}$ \\
\hline 1494R & TACGGCTACCTTGTTACGAC & $\begin{array}{l}\text { Neilan et al. (1997), } \\
\text { Weisburg et al. (1991) }\end{array}$ \\
\hline
\end{tabular}

(Perkin Elmer) according to the manufacturers' protocols. Sequencing products were separated on model 377 DNA Sequencer machines and analysed using programs contained in the INHERIT package (PE Applied Biosystems). Primers used for sequencing reactions are listed in Table 1. In all cases both strands of DNA were sequenced with contiguous overlaps.

Phylogenetic inferences. Sequences were aligned using the GCG program PILEUP, version 8 (Genetics Computer Group, Program Manual for the Wisconsin Package, 1994) and the multiple-sequence alignment and profile alignment tools in the CLUSTAL x package (Thompson et al., 1994). Aligned sequences were corrected manually and nucleotide positions that contained ambiguities were removed from further analysis. Genetic distances, corrected for multiple base changes by the method of Jukes \& Cantor (1969), were calculated using the DNADIST program in the PHYLIP package, version 3.57c (Felsenstein, 1989). The phylogenetic tree was reconstructed by the neighbour-joining method of Saitou \& Nei (1987) and the tree plotted using NJPLOT in the CLUSTAL $\mathrm{X}$ package. Bootstrap values were obtained from analysis of one hundred resamplings of the corrected alignment created using the program SEQBOOT (Felsenstein, 1985) and analysed using both distance (DNADIST) and parsimony (DNAPARS) algorithms and CONSENSE all from the PHYLIP package.

Biochemical characterization. Sixty-three phenotypic characteristics were determined for isolates using standardized methods performed as recommended in an extensive identification scheme designed for Campylobacter, Helicobacter and related bacteria (On et al., 1996). All tests were performed twice on separate occasions. Type and reference strains of $H$. rodentium were also examined for critical comparison with the putative new species. All tests were performed using freshly prepared media, whose quality was assured by appropriate control strains. Growth tolerance tests for both $H$. ganmani and $H$. rodentium were performed under anaerobic conditions.

SDS-PAGE of whole-cell proteins. Whole-cell protein extracts were prepared from isolates and SDS-PAGE was performed as described previously (Pot et al., 1994). The densitometric analysis, normalization and interpolation of the protein profiles, and numerical analysis were performed using the GelCompar software package version 4.2 (Applied Maths), and the profiles were recorded and stored on a PC computer. The similarity between all pairs of traces was expressed by the Pearson product-moment correlation coefficient and is presented as percentages of similarity.

\section{RESULTS}

\section{Isolation, growth characteristics and ultrastructure}

Out of a total of 110 spiral isolates cultured, 17 were isolated on BA in anaerobe jars fitted with anaerobic 


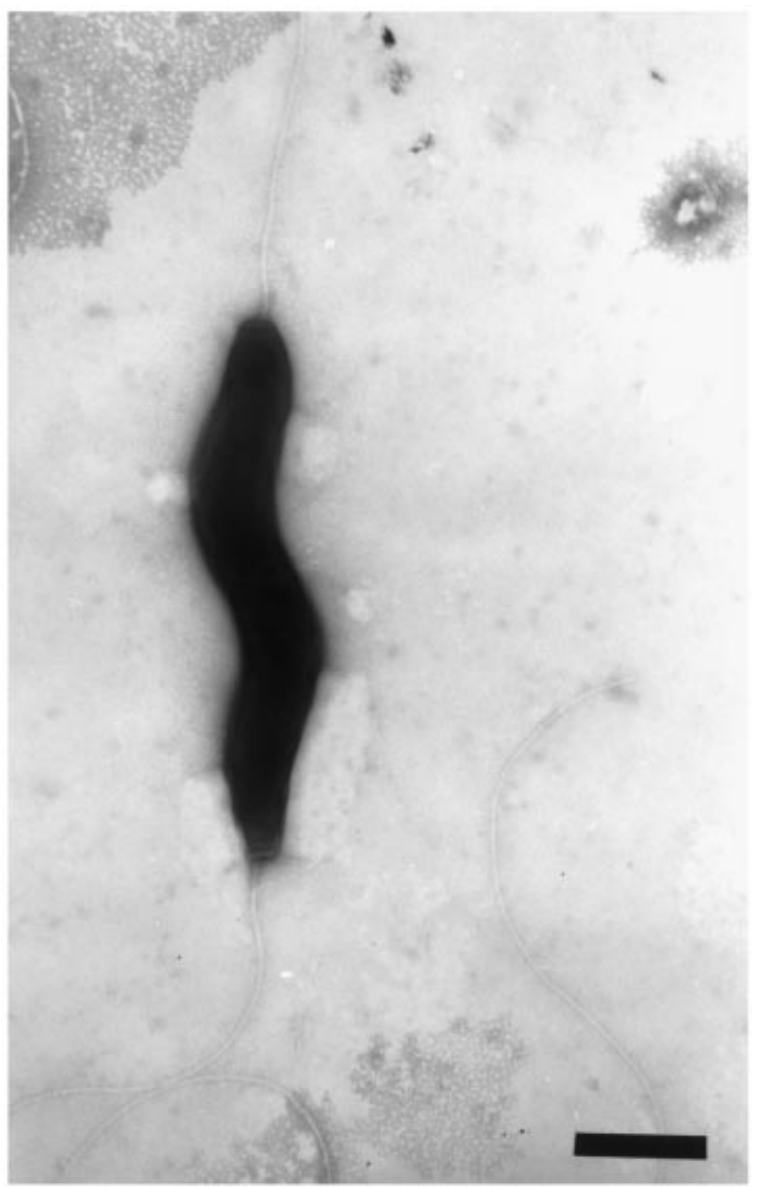

Fig. 1. Negative stain of Helicobacter ganmani $\mathrm{CMRI} \mathrm{HO}^{\top}$ showing spiral morphology and unsheathed, single, bipolar flagella. Bar, $0.5 \mu \mathrm{m}$. gas generating kits. These isolates were curved or spiral-shaped when observed in wet mounts using phase-contrast microscopy, were Gram-negative and not capable of growth under microaerobic conditions or on CSA under either microaerobic or anaerobic conditions. After $3-5 \mathrm{~d}$ incubation at $37^{\circ} \mathrm{C}$, growth appeared as a thin, transparent, spreading film. Single colonies $(<1 \mathrm{~mm}$ diameter) were isolated when the initial inoculation of intestinal mucus scraping was made onto membrane filters with a pore size of $0.65 \mu \mathrm{m}$ and were characterized by irregular edges, consistent with a spreading, motile organism. No isolates representing this group of bacteria were cultured from mice obtained from one of the animal facilities (conventional), while all spiral isolates cultured from mice from another facility (SPF) were members of this group $(n=9)$. Cultures were isolated from the small bowel $(1 / 17)$, caecum $(11 / 17)$, large bowel $(3 / 17)$ and liver $(2 / 17)$. Both cultures obtained from liver samples were from SPF animals obtained from a single facility. $H$. ganmani cells were $0 \cdot 3 \times 2 \cdot 5 \mu \mathrm{m}$ and possessed single, bipolar, unsheathed flagella (Fig. 1).

\section{DNA analysis}

All 17 isolates gave positive results in Helicobacter genus-specific PCRs. Near-complete 16S rDNA sequences were generated from four isolates (Table 2), and these sequences were identical to one another and had $98.2 \%$ sequence similarity to the type strain of $H$. rodentium (MIT 95-1707 ${ }^{\mathrm{T}}$ ) (Shen et al., 1997). They also had $100 \%$ sequence identity with a sequence from an unnamed mouse isolate, Helicobacter sp. MIT 95-2011 (GenBank no. U96298). DNA from all 17 isolates was subjected to a $H$. rodentium-specific PCR

Table 2. Helicobacter ganmani and Helicobacter rodentium strains examined

\begin{tabular}{|c|c|c|}
\hline Taxon & Strain/other designation & GenBank no. \\
\hline $\begin{array}{l}\text { Helicobacter ganmani } \\
\text { Helicobacter ganmani } \\
\text { Helicobacter ganmani } \\
\text { Helicobacter ganmani } \\
\text { Helicobacter ganmani } \\
\text { Helicobacter ganmani } \\
\text { Helicobacter ganmani } \\
\text { Helicobacter ganmani } \\
\text { Helicobacter ganmani } \\
\text { Helicobacter rodentium } \dagger \\
\text { Helicobacter rodentium } \dagger \\
\text { Helicobacter rodentium }\end{array}$ & $\begin{array}{l}\text { CMRI H02 } 2^{\mathrm{T}} \text {, CCUG } 43526^{\mathrm{T}}, \text { CIP } 106846^{\mathrm{T}} \\
\text { CMRI H03 } \\
\text { CMRI H04 } \\
\text { CMRI H09* } \\
\text { ABHU H11, CCUG } 43527 \\
\text { ABHU H13* } \\
\text { ABHU H15 } \\
\text { UNSW H16, CCUG } 43528 \\
\text { UNSW H17 } \\
\text { MIT 95-1707T, ATCC } 700285^{\mathrm{T}} \\
\text { MIT 95-2178 } \\
\text { MIT 95-2060 }\end{array}$ & $\begin{array}{l}\text { AF000221 } \\
\text { AF000222 } \\
\text { AF000223 } \\
\text { AF000224 } \\
\text { U96296\$ }\end{array}$ \\
\hline
\end{tabular}

* Strain not examined phenotypically.

$\dagger$ Strain kindly provided by J. G. Fox, Division of Comparative Medicine, Massachusetts Institute of Technology, Cambridge, MA, USA.

$\$ 16$ S rRNA sequence determined previously (Shen et al., 1997). 


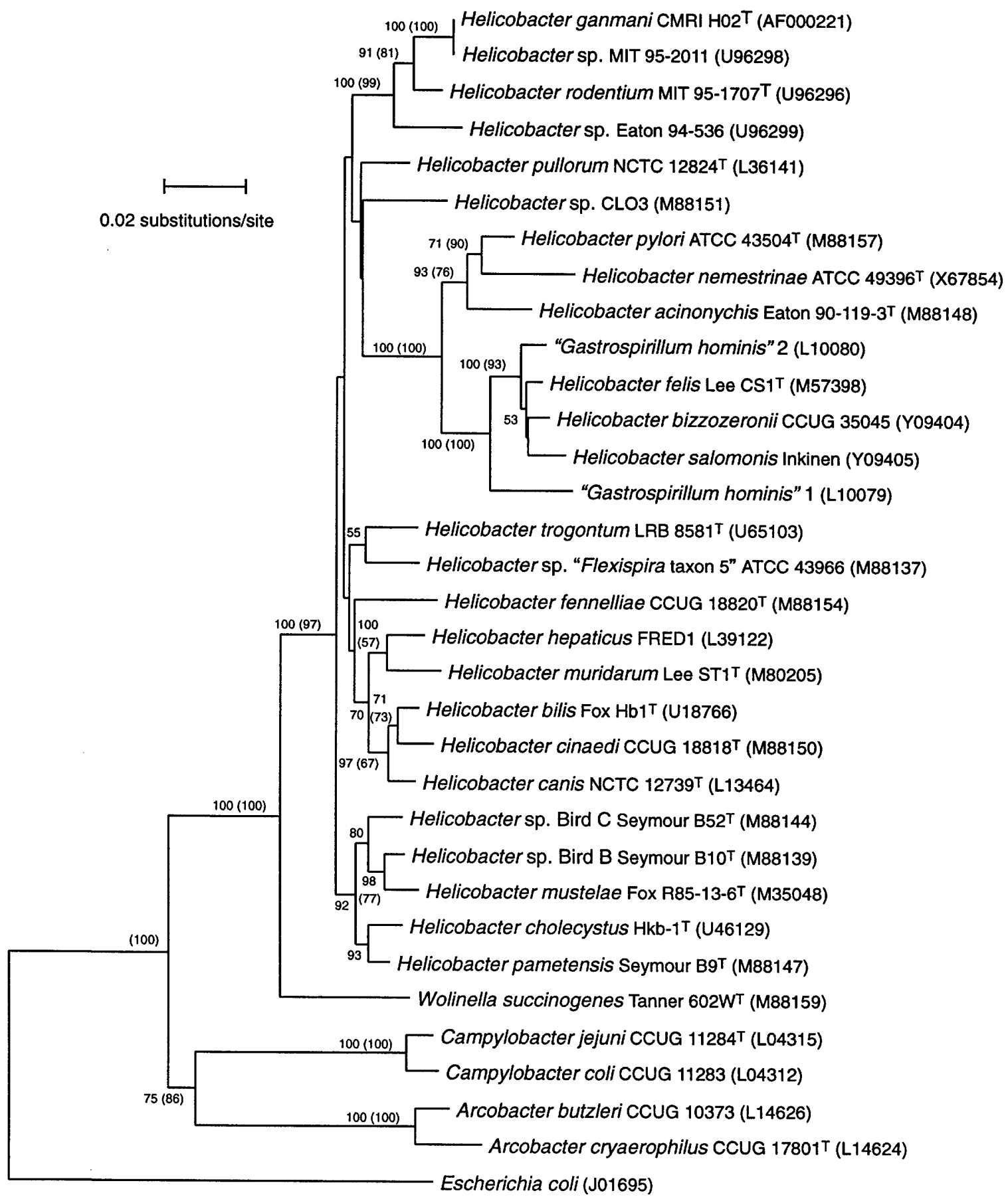

Fig. 2. Phylogenetic tree showing the position of Helicobacter ganmani based on analysis of near complete 165 rDNA sequences derived from members of the Helicobacter, Campylobacter and Arcobacter genera with Escherichia coli as the outgroup. Scale bar represents 0.02 substitutions per site. Significant bootstrap values $(>50 \%)$ from both distance and parsimony analyses are indicated at the nodes (parsimony values shown in parentheses).

using primers D86 and D87 (Table 1) as described by Shen et al. (1997). All samples were positive in this reaction. A phylogenetic tree was reconstructed from a multiple alignment of our consensus sequence with 32 other bacterial 16S rDNA sequences including members of the Helicobacter, Campylobacter and Arcobacter genera (Fig. 2). The alignment was 1358 nucleotides in length after positions containing ambiguities in any of the sequences were removed.

\section{Phenotypic characterization}

Seven strains of $H$. ganmani were examined (Table 2) and, as expected they bore a close resemblance to $H$. 
Table 3. Characteristics that differentiate culturable Helicobacter ganmani from other Helicobacter species

Taxa: 1, H. ganmani; 2, H. rodentium; 3, H. pylori; 4, H. nemestrinae; 5, H. acinonychis; 6, H. felis; 7, H. bizzozeronii; 8 , H. salomonis; 9, H. pullorum; 10, H. pametensis; 11, H. cholecystus; 12, H. mustelae; 13, H. fennelliae; 14, H. muridarum; 15, H. hepaticus; 16, H. trogontum; 17, H. canis; 18, H. bilis; 19, H. cinaedi. +, 80-100\% strains positive; v, 50-67\% strains positive; d, 20-43\% strains positive; - , 0-17\% strains positive; ND, not determined. TTC, triphenyl-tetrazolium chloride. All biochemical results (except $H$. bilis) obtained using the standardized methods recommended for use with the identification scheme of On et al. (1996). Distribution of flagella: Bp, bipolar; Mp, monoploar; Pe, peritrichous. Data taken from this study, Fox et al. (1995), On et al. (1996), Jalava et al. (1998), and unpublished results of S. L. W. On.

\begin{tabular}{|c|c|c|c|c|c|c|c|c|c|c|c|c|c|c|c|c|c|c|c|}
\hline Character & 1 & 2 & 3 & 4 & 5 & 6 & 7 & 8 & 9 & 10 & 11 & 12 & 13 & 14 & 15 & 16 & 17 & 18 & 19 \\
\hline Catalase production & $-/ w$ & + & + & + & + & + & + & + & + & + & + & + & + & + & + & + & - & + & + \\
\hline Nitrate reduction & + & + & - & - & - & + & + & + & + & + & + & + & - & - & + & + & - & + & + \\
\hline Alkaline phosphatase hydrolysis & - & - & + & + & + & $\mathrm{v}$ & $\mathrm{v}$ & $\mathrm{v}$ & - & + & + & + & $\mathrm{d}$ & + & - & - & + & - & $\mathrm{d}$ \\
\hline Urease & - & - & + & + & + & + & + & + & - & - & - & + & - & + & + & + & - & + & - \\
\hline Indoxyl acetate hydrolysis & - & - & - & - & $\mathrm{d}$ & $\mathrm{d}$ & $\mathrm{d}$ & - & - & - & - & + & + & + & + & - & + & - & - \\
\hline Growth at $42{ }^{\circ} \mathrm{C}$ & - & + & $\mathrm{d}$ & + & $\mathrm{d}$ & $\mathrm{v}$ & $\mathrm{v}$ & - & + & + & + & $\mathrm{v}$ & $\mathrm{d}$ & - & - & + & + & + & $\mathrm{d}$ \\
\hline Growth on CCDA & + & - & - & - & $\mathrm{d}$ & - & - & - & $\mathrm{v}$ & - & - & - & - & - & - & - & - & ND & - \\
\hline Tolerance to $1.0 \%$ glycine & - & + & - & - & - & - & - & - & - & $\mathrm{v}$ & + & - & - & - & + & + & - & + & - \\
\hline Tolerance/redn of $0.04 \%$ TTC & + & $\mathrm{v}$ & $\mathrm{d}$ & + & - & - & - & - & $\mathrm{d}$ & $\mathrm{v}$ & + & + & + & - & + & + & $\mathrm{v}$ & $\mathrm{ND}$ & + \\
\hline Periplasmic fibres & - & - & - & - & - & + & - & - & - & - & - & - & - & + & - & + & - & + & - \\
\hline Sheathed flagella & - & - & + & + & + & + & + & + & - & + & + & + & + & + & + & + & + & + & + \\
\hline No. flagella & 2 & 2 & $4-8$ & $4-8$ & $2-5$ & $14-20$ & $10-20$ & $10-23$ & 1 & 2 & 1 & $4-8$ & 2 & $10-14$ & 2 & $5-7$ & 2 & $3-14$ & $1-2$ \\
\hline Distribution of flagella & $\mathrm{Bp}$ & Bp & $\mathrm{Bp}$ & $\mathrm{Bp}$ & $\mathrm{Bp}$ & $\mathrm{Bp}$ & $\mathrm{Bp}$ & Bp & $\mathrm{Mp}$ & $\mathrm{Bp}$ & $\mathrm{Mp}$ & $\mathrm{Pe}$ & $\mathrm{Bp}$ & Bp & $\mathrm{Bp}$ & $\mathrm{Bp}$ & $\mathrm{Bp}$ & $\mathrm{Bp}$ & $\mathrm{Mp} / \mathrm{Bp}$ \\
\hline
\end{tabular}
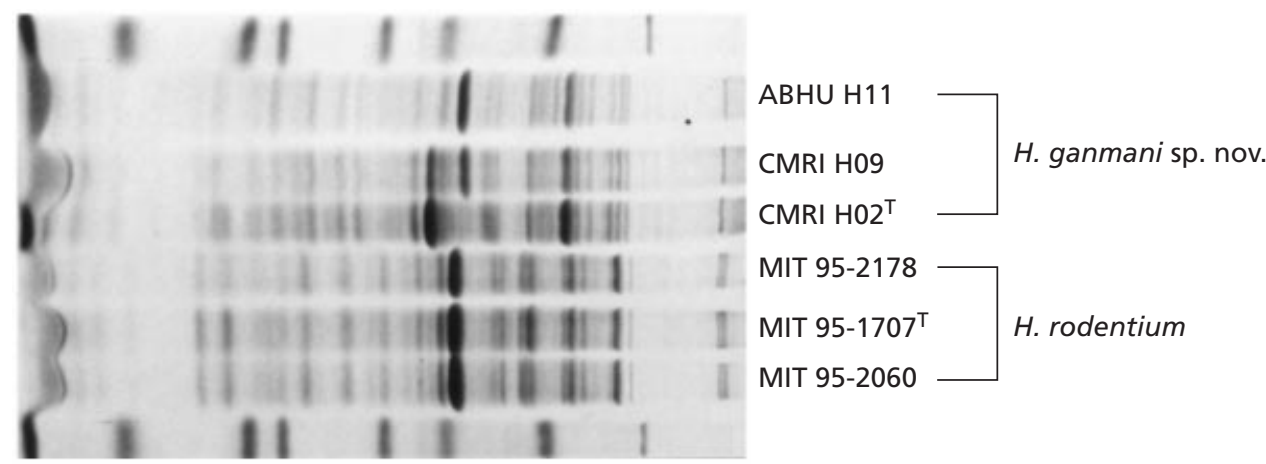

Fig. 3. Whole-cell protein profiles of a representative selection of $H$. ganmani strains showing the three protein electrophoretic types and of the $H$. rodentium strains examined. The molecular mass markers used (top and bottom lanes) are indicated from left to right: lysozyme (14.5 kDa), trypsin inhibitor (20.1 kDa), trypsinogen (24 kDa), carbonic anhydrase $(29 \mathrm{kDa})$, glyceraldehyde-3-phosphate dehydrogenase $(36 \mathrm{kDa})$, egg albumin $(45 \mathrm{kDa})$, bovine albumin $(66 \mathrm{kDa})$ and $\beta$-galactosidase (116 kDa).

rodentium. Nonetheless, these species were differentiated on the basis of $\alpha$-haemolytic activity and ability to grow at $42{ }^{\circ} \mathrm{C}$ and on Campylobacter charcoaldeoxycholate agar base medium (CCDA). H. ganmani was also distinct from other extant species (Table 3 ). The phenotype of the new species is described in detail below.

\section{SDS-PAGE of whole-cell proteins}

The whole-cell protein profiles of nine $H$. ganmani isolates (Table 2) were compared with those of $H$. rodentium reference strains and other Helicobacter species already present in the database. The $H$. rodentium reference strains had virtually identical whole-cell protein profiles. The nine $H$. ganmani isolates examined were subdivided into three subgroups, characterized by the presence or the absence of dense protein bands with approximate molecular masses of 47 and $43 \mathrm{kDa}$. One subgroup had both protein bands, a second had only a dense $47 \mathrm{kDa}$ protein band, while the third had only a dense $43 \mathrm{kDa}$ protein band. Fig. 3 illustrates the three different protein electrophoretic types within $H$. ganmani and the whole-cell protein profiles of the $H$. rodentium strains. In a numerical analysis of the whole-cell protein profiles of all strains examined and of Helicobacter reference strains, the three different protein electrophoretic types of $H$. ganmani strains formed distinct clusters (data not shown). When the region with these variable dense protein bands was omitted 


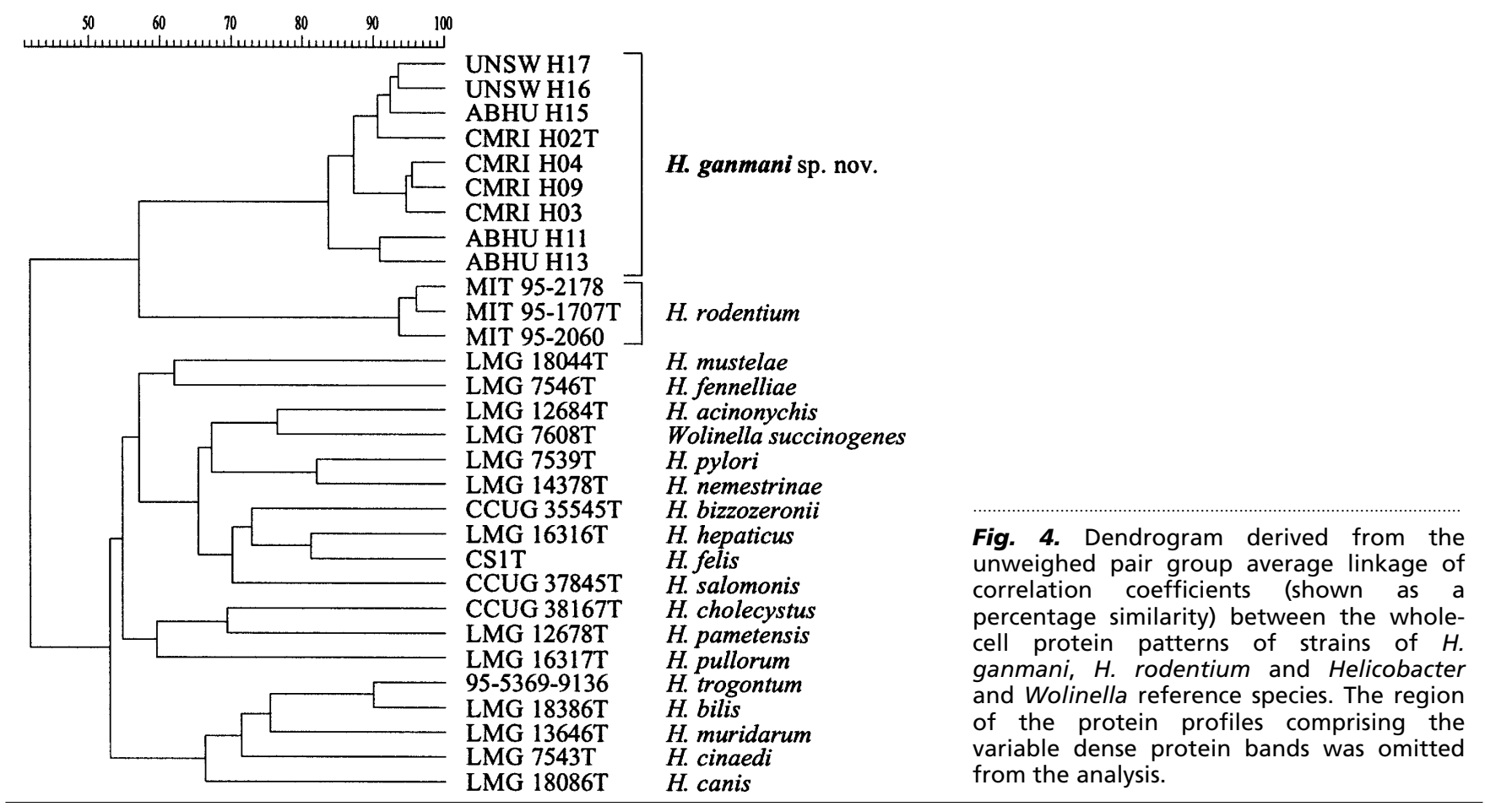

from the numerical comparison, all strains clustered tightly together (Fig. 4).

\section{DISCUSSION}

The results from our investigations presented here support the establishment of a novel species of Helicobacter for which we propose the name Helicobacter ganmani. Isolates were cultured from all sections of the intestinal tract of mice examined, however, the caecum appeared to be the preferred site of colonization. Isolates were obtained from both conventional and SPF mice and were also isolated from liver samples of SPF animals which had no evidence of infection with other Helicobacter species. This is the first report of a Helicobacter species which grows exclusively in an anaerobic atmosphere provided by standard anaerobic jars and gas-generating kits. Many other Helicobacter species are capable of anaerobic growth but are routinely cultured using microaerobic conditions. However, we found only one strain of $H$. rodentium grew under microaerobic conditions provided by the gas-replacement method used here. This result is in contrast with that of Shen et al. (1997), but differences in the methods used to generate microaerobic conditions between laboratories may account for this discrepancy.

$H$. ganmani possesses unsheathed flagella, bringing to three, with $H$. rodentium and Helicobacter pullorum, the number of Helicobacter species lacking sheathed flagella (Shen et al., 1997; Stanley et al., 1994). 16S rDNA sequence analysis revealed a close phylogenetic relationship between $H$. ganmani and $H$. rodentium and all of our isolates were amplified in the $H$. rodentium-specific PCR as described by Shen et al. (1997). This result was not surprising considering the level of sequence similarity between these two species, and closer examination of the $16 \mathrm{~S}$ rDNA sequence of four $H$. ganmani isolates revealed that the target sites for primers D86 and D87 were indeed present. It should be noted, therefore, that $H$. rodentium cannot be positively identified using this PCR to the exclusion of $H$. ganmani. A PCR designed to differentiate between these species was not developed. The high level of sequence similarity between $H$. rodentium and $H$. ganmani, and problems encountered with lab-to-lab reproducibility would render such a reaction of limited practical use. While the sequence similarity observed between these two species was above the level that allows discrimination between closely related species (Stackebrandt \& Goebel, 1994), data obtained from SDS-PAGE of whole-cell proteins clearly discriminated them as separate species (Figs 3 and 4). Numerical analysis of SDS-PAGE of whole-cell protein extracts has been recommended by the International Committee on Systematic Bacteriology Subcommittee on the taxonomy of Campylobacter and related bacteria as a suitable alternative to DNADNA hybridization studies for discriminating between closely related species of Helicobacter (Dewhirst et al., 2000). The nine H. ganmani strains examined using this technique clustered into three protein electrophoretic subgroups, each containing three isolates. With one exception, these groups contained strains isolated from animals housed at a single facility (data not shown). Such intraspecies variability has been observed for many Helicobacter and Campylobacter species, but the 
overall pattern was virtually identical for all isolates. Previous studies with other Campylobacter-like organisms characterized by similar variable dense protein bands as those observed here have shown that such variable regions must be omitted from the numerical analysis in order to locate the different protein electrophoretic types of a single species into a single cluster (Costas et al., 1987; Owen et al., 1989; Vandamme et al., 1990, 1992). This was confirmed in the present study (Fig. 4). Detailed phenotypic analysis of seven strains revealed that $H$. ganmani and $H$. rodentium shared many biochemical properties, notably a lack of urease and alkaline phosphatase activities, and failure to hydrolyse indoxyl acetate, but were clearly distinguished from each other and from other Helicobacter species (Table 3). These differences further support out proposal for a new Helicobacter species.

$H$. ganmani represents the 19th named species of Helicobacter and reinforces once again the diversity of species that naturally infect rodents and, significantly, laboratory mice. We strongly support the recommendation of Shen et al. (1997) for screening of laboratory mice for indigenous Helicobacter spp. in laboratories engaging in any area of Helicobacter research, particularly in immunological and vaccine studies.

\section{Description of Helicobacter ganmani sp. nov.}

Helicobacter ganmani (gan.man'i. N.L. gen. n. ganmani arbitrary name derived from ganman which, in the language of the Gadigal people, indigenous Australians who live in the Sydney Harbour area, means 'snake finder'. Thus, 'ganman' refers to the spiral or 'snake-like' morphology and the fact that this organism was isolated from mice in Sydney, Australia, the home of the Gadigal people).

Cells are curved to spiral rods $(0.3 \times 2.5 \mu \mathrm{m})$ with two turns per cell and have single, unsheathed flagella in a bipolar arrangement. Single colonies are rarely seen and are $<1 \mathrm{~mm}$ in diameter, irregular, unpigmented and translucent, after $3-5 \mathrm{~d}$ growth on $5 \%$ horse blood agar. Anaerobic; no growth obtained in microaerobic or aerobic conditions. Pitting of the agar not observed. All strains produce oxidase. Weak catalase activity detected (2/7 strains). Nitrate and triphenyltetrazolium chloride (TTC) reduced. No urease, alkaline phosphatase, hippuricase or DNase activity detected. Selenite not reduced. Indoxyl acetate not hydrolysed. Neither hydrogen sulphide nor acid from sugar fermentation produced in triple-sugar iron agar. Non-haemolytic. All strains grow anaerobically at $37^{\circ} \mathrm{C}$ on Campylobacter charcoal-deoxycholate (CCD) agar, and on media containing $0.1 \%$ trimethylamine $N$-oxide (TMAO), 1.0 and $2.0 \%$ ox-bile, $0.04 \%$ TTC, $32 \mathrm{mg}$ cephalothin $\mathrm{1}^{-1}, 32 \mathrm{mg}$ carbenicillin $\mathrm{1}^{-1}$ (BA base), $64 \mathrm{mg}$ cefoperazone $\mathrm{l}^{-1}$ (BA base), 5fluorouracil or $0.1 \%$ sodium fluoride. No growth obtained anaerobically at room temperature (18$22{ }^{\circ} \mathrm{C}$ ), 25 or $42{ }^{\circ} \mathrm{C}$, on tyrosine or casein media, or on media containing $1.0 \%$ glycine, $2-4 \% \mathrm{NaCl}, 32 \mathrm{mg}$ nalidixic acid $1^{-1}, 0 \cdot 0005 \%$ crystal violet, $0 \cdot 1 \%$ janus green or $0.02 \%$ pyronin. Growth on $0.032 \%$ methyl orange media ( $6 / 7$ strains), minimal and $0.005 \%$ basic fuchsin media ( $5 / 7$ strains) and $4 \mathrm{mg}$ metronidazole $\mathrm{l}^{-1}$ (BA medium) (3/7 strains). Strains do not always give reproducible results when tested for growth on MacConkey, $0.1 \%$ sodium deoxycholate or $0.02-$ $0.05 \%$ safranin media. Cells have been isolated from caeca, large bowels, small bowels and livers of mice. The type strain is CMRI H02 ${ }^{\mathrm{T}}$ (= CCUG $43526^{\mathrm{T}}=$ CIP $106846^{\mathrm{T}}$ ). When a difference in phenotype was observed between strains, the description given above applies to the type strain, CMRI $\mathrm{HO}^{\mathrm{T}}$.

\section{ACKNOWLEDGEMENTS}

Wendy Brady and the Indigenous Members of the Management Committee of the Aboriginal Research and Resource Centre (UNSW, Australia) and Aboriginal members of the History Council of NSW are thanked for their suggestions and advice regarding the Gadigal language and use of 'ganman' as the basis for the name of this new species. We are grateful to George Mendz (UNSW) and Hans Trüper (University of Bonn, Germany) for helping with the correct formation of the species name. Automated sequencing was performed at the UNSW Automated DNA Analysis Facility. Strains of $H$. rodentium were kindly provided by James Fox (Massachusetts Institute of Technology).

\section{REFERENCES}

Costas, M., Owen, R. J. \& Jackman, P. J. H. (1987). Classification of Campylobacter sputorum and allied campylobacters based on numerical analysis of electrophoretic protein patterns. Syst Appl Microbiol 9, 125-131.

De Ley, J. (1992). The Proteobacteria: ribosomal RNA cistron similarities and bacterial taxonomy. In The Prokaryotes, pp. 2111-2140. Edited by A. Balows, H. G. Trüper, M. Dworkin, W. Harder \& K. H. Schleifer. New York: Springer.

Dewhirst, F. E., Fox, J. G. \& On, S. L. W. (2000). Recommended minimal standards for describing new species of the genus Helicobacter. Int J Syst Evol Microbiol 50, 2231-2237.

Felsenstein, J. (1985). Confidence limits on phylogenetics: an approach using the bootstrap. Evolution 39, 783-791.

Felsenstein, J. (1989). PHYLIP. Phylogeny inference package. Cladistics 5, 164-166.

Fox, J. G. \& Wang, T. C. (1997). Helicobacter and liver disease. Ital $J$ Gastroenterol Hepatol 29, 5-12.

Fox, J. G., Paster, B. J., Dewhirst, F. E., Taylor, N. S., Yan, L. L., Macuch, P. J. \& Chmura, L. M. (1992). Helicobacter mustelae isolation from feces of ferrets: evidence to support fecal-oral transmission of a gastric helicobacter. Infect Immun 60, 606-611.

Fox, J. G., Dewhirst, F. E., Tully, J. G., Paster, B. J., Yan, L., Taylor, N. S., Collins, M. J., Gorelick, P. L. \& Ward, J. M. (1994). Helicobacter hepaticus sp. nov., a microaerophilic bacterium isolated from livers and intestinal mucosal scrapings from mice. $J$ Clin Microbiol 32, 1238-1245.

Fox, J. G., Yan, L. L., Dewhirst, F. E., Paster, B. J., Shames, B., Murphy, J. C., Hayward, A., Belcher, J. C. \& Mendes, E. N. (1995). Helicobacter bilis sp. nov., a novel Helicobacter species isolated 
from bile, livers, and intestines of aged, inbred mice. $J$ Clin Microbiol 33, 445-454.

Goodwin, C. S., Armstrong, J. A., Chilvers, T., Peters, M., Collins, M. D., Sly, L., McConnell, W. \& Harper, W. E. (1989). Transfer of Campylobacter pylori and Campylobacter mustelae to Helicobacter gen. nov. as Helicobacter pylori comb. nov. and Helicobacter mustelae comb. nov., respectively. Int J Syst Bacteriol 39, $397-405$.

Jalava, K., On, S. L. W., Vandamme, P. A. R., Happonen, I., Sukura, A. \& Hänninen, M.-L. (1998). Isolation and identification of Helicobacter spp. from canine and feline gastric mucosa. Appl Environ Microbiol 64, 3998-4006 [erratum 65, 887 (1999)].

Jukes, T. H. \& Cantor, C. R. (1969). Evolution of protein molecules. In Mammalian Protein Metabolism, vol. 3, pp. 21-132. Edited by H. N. Munro. New York: Academic Press.

Lee, A., Phillips, M. W. \& O'Rourke, J. L. \& 8 other authors (1992). Helicobacter muridarum sp. nov., a microaerophilic helical bacterium with a novel ultrastructure isolated from the intestinal mucosa of rodents. Int J Syst Bacteriol 42, 27-36.

Lee, A., O'Rourke, J., De Ungria, M. C., Robertson, B., Daskalopolous, G. \& Dixon, M. F. (1997). A standardardized mouse model of Helicobacter pylori infection: introducing the Sydney strain. Gastroenterology 112, 1386-1397.

Marshall, B. J., Royce, H., Annear, D. I., Goodwin, C. S., Pearman, J. W., Warren, J. R. \& Armstrong, J. A. (1984). Original isolation of Campylobacter pyloridis from human gastric mucosa. Microbiol Lett 25, 83-88.

Mendes, E. N, Queiroz, D. M. M., Dewhirst, F. E., Paster, B. J., Moura, S. B. \& Fox, J. G. (1996). Helicobacter trogontum sp. nov., isolated from the rat intestine. Int J Syst Bacteriol 46, 916-921.

Murray, R. G. E., Brenner, D. J., Colwell, R. R., De Vos, P., Goodfellow, M., Grimont, P. A. D., Pfennig, N., Stackebrandt, E. \& Zavarzin, G. A. (1990). International Committee on Systematic Bacteriology. Report of the ad hoc committee on approaches to taxonomy within the Proteobacteria. Int J Syst Bacteriol 40, 213-215.

Neilan, B. A., Jacobs, D., Del Dot, T., Blackall, L. L., Hawkins, P. R., Cox, P. T. \& Goodman, A. E. (1997). rRNA sequences and evolutionary relationships among toxic and nontoxic cyanobacteria of the genus Microcystis. Int J Syst Bacteriol 47, 693-697.

On, S. L. W., Holmes, B. \& Sackin, M. J. (1996). A probability matrix for the identification of campylobacters, helicobacters, and allied taxa. J Appl Bacteriol 81, 425-432.

Owen, R. J., Morgan, D. D., Costas, M. \& Lastovica, A. (1989). Identification of "Campylobacter upsaliensis" and other catalase-negative campylobacters from pediatric blood cultures by numerical analysis of electrophoretic protein patterns. FEMS Microbiol Lett 58, 145-150.

Pot, B., Vandamme, P. \& Kersters, K. (1994). Analysis of electrophoretic whole-organism protein fingerprints. In Modern Microbial Methods (Chemical Methods in Prokaryotic Systematics), pp. 493-521. Edited by M. Goodfellow \& A. G. O’Donnell. Chichester: Wiley.
Riley, L. K., Franklin, C. L., Hook, R. R., Jr \& Besch-Williford, C. (1996). Identification of murine helicobacters by PCR and restriction enzyme analyses. J Clin Microbiol 34, 942-946.

Saitou, N. \& Nei, M. (1987). The neighbor-joining method: a new method for reconstructing phylogenetic trees. Mol Biol Evol 4, 406-425.

Schauer, D. B., Ghori, N. \& Falkow, S. (1993). Isolation and characterization of "Flexispira rappini" from laboratory mice. J Clin Microbiol 31, 2709-2714.

Shames, B., Fox, J. G., Dewhirst, F., Yan, L., Shen, Z. \& Taylor, N. S. (1995). Identification of widespread Helicobacter hepaticus infection in feces in commercial mouse colonies by culture and PCR assay. J Clin Microbiol 33, 2968-2972.

Shen, Z., Fox, J. G., Dewhirst, F. E., Paster, B. J., Foltz, C. J., Yan, L., Shames, B. \& Perry, L. (1997). Helicobacter rodentium sp. nov., a urease-negative Helicobacter species isolated from laboratory mice. Int J Syst Bacteriol 47, 627-634.

Stackebrandt, E. \& Goebel, B. M. (1994). A place for DNA-DNA reassociation and $16 \mathrm{~S}$ rRNA sequence analysis in the present species definition in bacteriology. Int $J$ Syst Bacteriol 44, 846-849.

Stanley, J., Linton, D., Burnens, A. P., Dewhirst, F. E., On, S. L. W., Porter, A., Owen, R. J. \& Costas, M. (1994). Helicobacter pullorum sp. nov. - genotype and phenotype of a new species isolated from poultry and from human patients with gastroenteritis. Microbiology 140, 3441-3449.

Thompson, J. D., Higgins, D. G. \& Gibson, T. J. (1994). CLUSTAL $\mathrm{W}$ : improving the sensitivity of progressive multiple sequence alignment through sequence weighting, position specific gap penalties and weight matrix choice. Nucleic Acids Res 22, 4673-4680.

Tillett, D. \& Neilan, B. A. (2000). Rapid nucleic acid isolation from cultured and environmental cyanobacteria: novel techniques based on xanthogenate. $J$ Phycol 36, 251-258.

Vandamme, P. \& De Ley, J. (1991). Proposal for a new family, Campylobacteraceae. Int J Syst Bacteriol 41, 451-455.

Vandamme, P., Pot, B., Falsen, E., Kersters, K. \& De Ley, J. (1990). Intra- and interspecific relationships of veterinary campylobacters revealed by numerical analysis of electrophoretic protein profiles and DNA:DNA hybridizations. Syst Appl Microbiol 13, 295-303.

Vandamme, P., Falsen, E., Rossau, R., Hoste, B., Segers, P., Tytgat, R. \& De Ley, J. (1991). Revision of Campylobacter, Helicobacter, and Wolinella taxonomy: emendation of generic descriptions and proposal of Arcobacter gen. nov. Int J Syst Bacteriol 41, 88-103.

Vandamme, P., Dewettinck, D. \& Kersters, K. (1992). Application of numerical analysis of electrophoretic protein profiles for the identification of thermophilic campylobacters. Syst Appl Microbiol 15, 402-408.

Weisburg, W. G., Oyaizu, Y., Oyaizu, H. \& Woese, C. R. (1985). Natural relationships between Bacteroides and flavobacteria. $J$ Bacteriol 164, 320-326.

Weisburg, W. G., Barns, S. M., Pelletier, D. A. \& Lane, D. J. (1991). $16 \mathrm{~S}$ ribosomal DNA amplification for phylogenetic study. $J$ Bacteriol 173, 697-703. 